\title{
Square Centimeter
}

National Cancer Institute

\section{Source}

National Cancer Institute. Square Centimeter. NCI Thesaurus. Code C48460.

A CGS unit of area measurement equal to a square measuring one centimeter on each side. One square centimeter is equal to $10 \mathrm{E}-4$ square meter. 